\title{
Numerical Taxonomy of Saccharolytic Clostridia, Particularly Clostridium perfringens-Like Strains: Descriptions of Clostridium absonum sp. $\mathrm{n}$. and Clostridium paraperfringens
}

\author{
SHINICHI NAKAMURA, TOMO SHIMAMURA, MITSURU HAYASE, and SHOKI NISHIDA \\ Department of Bacteriology, School of Medicine, Kanazawa University, Kanazawa, Japan
}

\begin{abstract}
Clostridium perfringens-like strains whose taxonomic position is uncertain were examined in detail. The lecithinases of these strains exhibited less avidity to the alpha-antitoxin of $C$. perfringens than did the $C$. perfringens lecithinase. On the basis of a computer analysis, the $C$. perfringens-like strains were grouped into two phenons, I and III, both of which are distinctly separable from $C$. perfringens (phenon II). Strains previously identified by us as belonging to Clostridium paraperfringens Nakamura et al. 1970, including strain G (= ATCC 27639), here designated as the type strain of $C$. paraperfringens, were found to belong to phenon I, and the strains of phenon III are regarded as constituting a new species, for which we propose the name Clostridium absonum. The type strain of $C$. absonum is HA-7103 (= ATCC 27555). The main characters differentiating $C$. absonum from $C$. perfringens are as follows: $C$. absonum produces a lecithinase which exhibits extremely low avidity to $C$. perfringens alpha-antitoxin, rapidly ferments salicin, does not ferment raffinose, and does not liquefy $10 \%$ gelatin; the main characters of $C$. absonum which differentiate it from phenon I strains are: larger cell width, a distinctly stronger lecithinase reaction, liquefaction of $2 \%$ gelatin, production of butanol, and weak toxicity for mice. Deoxyribonucleic acid (DNA)-DNA homology studies of phenons I, II, and III confirmed the validity of the above-mentioned groupings. A computer analysis of other saccharolytic clostridia revealed that $C$. butyricum, $C$. acetobutyricum, and $C$. multifermentans are associated by similarity values higher than $90 \%$ and that $C$. septicum and $C$. chauvoei constitute separate, but closely related, taxa.
\end{abstract}

In a previous communication, Nakamura et al. (15) proposed a new species, Clostridium paraperfringens, for strains isolated from a case of gas gangrene, from normal human intestines, and from soil samples. A type strain was not designated for this new species. The lecithinases produced by most of these $C$. perfringens-like strains on half-antitoxin Nagler agar (26) were completely suppressed by an excessive amount of $C$. perfringens antitoxin although they exhibited less avidity to $C$. perfringens alphaantitoxin than did the lecithinase of $C$. perfringens. These strains were nontoxic. Later, we encountered another group of $C$. perfringenslike strains which were toxigenic. The present work was carried out to elucidate the taxonomic relationship of the above-mentioned groups of $C$. perfringens-like strains to $C$. perfringens as well as to other saccharolytic clostridia by the use of numerical taxonomy, to detect their genetic relatedness by deoxyribonucleic acid (DNA)-DNA homology analysis, and to designate the type strain of $C$. paraperfringens. Because no computer analysis has been performed on clostridia to date, we also considered it worthwhile to examine a number of saccharolytic strains by this method, particularly those belonging to $C$. septicum and $C$. chauvoei.

\section{MATERIALS AND METHODS}

Bacterial strains. The strains used in this study are listed in Table 1. The isolation of $C$. perfringens-like strains was performed by the same method as that used for $C$. perfringens (28). 
Lecithinase. Lecithinase production was detected on an egg-yolk plate according to the method of Willis and Hobbs (26), and the activity of the lecithinase in culture filtrate was estimated by two methods, egg units (EU)/ml according to van Heyningen's method (25), and alpha-antitoxin equivalent $(\mathrm{AE}) / \mathrm{ml}$ according to Evans' method (6). The medium used was previously described by Nishida et al. (16). To make a half-antitoxin egg-yolk plate, a $0.1-\mathrm{ml}$ portion of $C$. perfringens type A antitoxin (600 International Units/ml; Chiba Serum Institute, Chiba, Japan) was spread over one-half of an egg-yolk plate.

DNA-DNA homology. Cells for DNA isolation were grown in a medium containing $2 \%$ (wt/vol) proteose peptone (Difco), $0.5 \%$ yeast extract, $0.5 \% \mathrm{NaCl}, 1 \%$ (wt/vol) glucose, and $0.1 \%$ sodium thioglycolate $(\mathrm{pH}$ 7.2). For isolation of ${ }^{32} \mathrm{P}$-labeled DNA, $0.1 \mathrm{mCi}$ of carrier-free ${ }^{32} \mathrm{P}$ was added to $100 \mathrm{ml}$ of the

TABLE 1. Strains used for computer analysis ${ }^{a}$

\begin{tabular}{|c|c|c|c|}
\hline $\begin{array}{c}\text { Strain } \\
\text { no. }\end{array}$ & Name & $\begin{array}{c}\text { Strain } \\
\text { no. }\end{array}$ & Name \\
\hline 1 & Clostridium paraperfringens FIS- $1 \mathrm{~W}(\mathrm{KZ})$ & 33 & C. septicum $8(\mathrm{NIHJ})$ \\
\hline 2 & C. paraperfringens FIS- $5(\mathrm{KZ})$ & 34 & C. septicum $94(\mathrm{NIHJ})$ \\
\hline 3 & C. paraperfringens $3-3(\mathrm{KZ})$ & 35 & C. septicum C-61 \\
\hline 4 & C. paraperfringens $9(\mathrm{KZ})$ & & (Gifu Univ., Gifu, Japan) \\
\hline 5 & C. paraperfringens $3-1(\mathrm{KZ})$ & 36 & C. septicum $7281(\mathrm{KZ})$ \\
\hline 6 & C. paraperfringens $\mathrm{G}(\mathrm{KZ})$ & 37 & C. septicum $616(\mathrm{KZ})$ \\
\hline 7 & C. paraperfringens $\mathrm{H}(\mathrm{KZ})$ & 38 & C. chauvoei Holland(SVSL) \\
\hline 8 & C. paraperfringens 2227 & 39 & C. chauvoei Frankring(SVSL) \\
\hline & $\begin{array}{l}\text { originally labeled Inflabilis barati } 2227 \text {, Pasteur } \\
\text { Institute, Paris }\end{array}$ & $\begin{array}{l}40 \\
41\end{array}$ & $\begin{array}{l}\text { C. chauvoei Mфrkov(SVSL) } \\
\text { C. chauvoei AA-1 1(SVSL) }\end{array}$ \\
\hline 9 & $\begin{array}{l}\text { C. paraperfringens } 7606 \\
\text { originally labeled } I . \text { barati } 7606, \text { Pasteur Institute, } \\
\text { Paris }\end{array}$ & 42 & $\begin{array}{l}\text { C. chauvoei C-59 } \\
\text { (Gifu Univ., Gifu, Japan) } \\
\text { C. chauvoei CH6 }\end{array}$ \\
\hline 10 & $\begin{array}{l}\text { C. paraperfringens } 12 / 16 \mathrm{~B} \\
\text { originally labeled } I \text {. lacustris } 12 / 16 \mathrm{~B} \text {, Pasteur In- } \\
\text { stitute, Paris }\end{array}$ & $\begin{array}{l}44 \\
45\end{array}$ & $\begin{array}{l}\text { (Leeds Univ., Leeds, England) } \\
\text { C. chauvoei } 11 \text { (NIHJ) } \\
\text { C. paraputrificum ATCC } 17864\end{array}$ \\
\hline 11 & C. perfringens type A PB6K(NIHJ) & 46 & C. innocuum ATCC 14501 \\
\hline 12 & C. perfringens type A S002-3(KZ) & 47 & C. botulinum type E 59 \\
\hline 13 & C. perfringens type A S $16550(\mathrm{KZ})$ & & (Institute of Health of Akita, Akita, \\
\hline 14 & C. perfringens type A $1610(\mathrm{KZ})$ & & Japan) \\
\hline 15 & C. perfringens type A S16102(KZ) & 48 & C. sphenoides ATCC 3560 \\
\hline 16 & C. perfringens type A $1278 \mathrm{~A}$ & 49 & C. bifermentans $315(\mathrm{KZ})$ \\
\hline & $\begin{array}{l}\text { originally labeled } I \text {. sanguicole } 1278 \mathrm{~A} \text {, Pasteur In- } \\
\text { stitute, Paris }\end{array}$ & 50 & $\begin{array}{l}\text { C. sordellii } 4708 \\
\text { (Wellcome Research Laboratory Col- }\end{array}$ \\
\hline 17 & C. perfringens type B NCTC 4964 & & lection, England) \\
\hline 18 & C. perfringens type C NCTC 3182 & 51 & C. sordellii $12 / 16 \mathrm{C}$ \\
\hline 19 & $\begin{array}{l}\text { C. perfringens type D L9 } \\
\text { (Leeds Univ., Leeds, England) }\end{array}$ & & $\begin{array}{l}\text { originally labeled } I \text {. lacustris } 12 / 16 \mathrm{C} \text {, } \\
\text { Pasteur Institute, Paris }\end{array}$ \\
\hline 20 & C. perfringens type E 411 (TSCI) & 52 & C. sporogenes $80011(\mathrm{KZ})$ \\
\hline 21 & C. perfringens type F 398(TSCI) & 53 & C. difficile ATCC 17857 \\
\hline 22 & C. perfringens type $\mathrm{F} 410$ (TSCI) & 54 & C. difficile ATCC 9689 \\
\hline 23 & C. tertium $2 \mathrm{C} 1-1(\mathrm{KZ})$ & 55 & C. difficile 2866 \\
\hline 24 & C. tertium $4 \mathrm{C}-2(\mathrm{KZ})$ & & originally labeled $I$. setiensis 2866 , Pas- \\
\hline 25 & C. tertium 965 & & teur Institute, Paris \\
\hline & $\begin{array}{l}\text { originally labeled Plectridium pseudo-tetanicum, } \\
\text { Pasteur Institute, Paris }\end{array}$ & 56 & $\begin{array}{l}\text { C. fallax A33H } \\
\text { Pasteur Institute, Paris }\end{array}$ \\
\hline 26 & C. multifermentans ATCC 17795 & 57 & C. tetani $\mathrm{PO} 5(\mathrm{KZ})$ \\
\hline 27 & C. multifermentans $2 \mathrm{C}-2(\mathrm{KZ})$ & 58 & C. tetanomorphum NCTC 288 \\
\hline 28 & C. butyricum IFO 3847 & 59 & Unidentified HA-7103(KZ) \\
\hline 29 & C. butyricum IFO 3858 & 60 & Unidentified HA-7107(KZ) \\
\hline 30 & C. acetobutyricum IFO 3346 & 61 & Unidentified HA-9103(KZ) \\
\hline 31 & C. acetobutyricum IFO 3859 & 62 & Unidentified SO6-4(KZ) \\
\hline 32 & C. septicum $5(\mathrm{NIHJ})$ & 63 & Unidentified TFI(KZ) \\
\hline
\end{tabular}

a Abbreviations: ATCC, American Type Culture Collection, Rockville, Md., U.S.A.; IFO, Institute for Fermentation, Osaka, Japan; KZ, strain isolated in Kanazawa, Japan; NIHJ, National Institute of Health, Tokyo, Japan; TSCI, Tarrasevich State Control Institute, Moscow, U.S.S.R.; SVSL, State Veterinary Serum Laboratory, Copenhagen, Denmark; NCTC, National Collection of Type Cultures, London, England. 
above-mentioned medium. All organisms were incubated at $37 \mathrm{C}$. Bacteria grown to the logarithmic phase were harvested by centrifugation and washed once with $1 \times$ SSC $(0.15 \mathrm{M} \mathrm{NaCl}$ and $0.015 \mathrm{M}$ sodium citrate). Highly polymerized DNA was prepared by the method of Marmur (12). The cells thus obtained were suspended in $0.1 \mathrm{M}$ ethylenediamine tetraacetic acid SSC (X 1) solution, and treated at $37 \mathrm{C}$ for $20 \mathrm{~min}$ with $1 \mathrm{mg}$ of lysozyme per $\mathrm{ml}$ (Boehringer Manheim $\mathrm{GmbH}$, Manheim, Germany). Sodium lauryl sulfate was added to a final concentration of $3 \%(\mathrm{wt} / \mathrm{vol}$ ), and the cell lysate was kept at $60 \mathrm{C}$ for $10 \mathrm{~min}$. The suspension was cooled to room temperature and deproteinized two or more times with chloroformoctyl alcohol. Ribonucleic acid (RNA) was removed by treatment with ribonuclease (RNase) (Worthington Biochemical Corp., Illinois). The labeled DNA was sheared by passing it through a French pressure cell $\left(12,000\right.$ to $\left.15,000 \mathrm{lb} / \mathrm{in}^{2}\right)$ (Otake, Tokyo, Japan). DNA, either native or sheared, was denatured by heating for $5 \mathrm{~min}$ at $100 \mathrm{C}$. The procedure for preparation of DNA-agar was carried out according to the method described by McCarthy and Hoyer (11). DNA was trapped in a $3 \%$ (wt/vol) agar (Oxoid lonagar no. 2) suspension. Hybridization was carried out by incubating at $60 \mathrm{C}$ for $14 \mathrm{~h}$ the mix ture of 0.1 $\mathrm{g}$ of DNA-agar containing 30 to $60 \mu \mathrm{g}$ of DNA and ${ }^{32}$ P-labeled DNA fragments of one-tenth the DNAagar in $1 \times \mathrm{SSC}$ according to the method of McCarthy and Bolton (10) as modified by Hanaoka et al. (8). Unbound DNA fragments were eluted with $2 \times \mathrm{SSC}$ at $60 \mathrm{C}$, and bound DNA was eluted with $0.01 \times \mathrm{SSC}$ at $70 \mathrm{C}$. Each fraction was collected and then counted in a liquid scintillation system, Unilex I-A (NuclearChicago Co., Des Plaines, Ill.). Experiments were performed in duplicate and, when further confirmation was necessary, were repeated.

Determination of similarity values. Strains examined were clustered by the single-linkage method described by Sneath (22). The data were coded according to procedure III of Beers et al. (2), and the similarity values were calculated as described by these same authors. The computer used was the NEAC 2230 (Nippon Electric Co., Tokyo, Japan). The properties used in the characterization of the organisms studied are listed in Table 2, and the number of features used was 152. Due to the morphological variability of clostridia, we did not use cell length as a character. The features of each strain were determined as follows. For morphological examinations, organisms were streaked on $1 \%$ glucose blood agar, and the plates were incubated for $36 \mathrm{~h}$ at $37 \mathrm{C}$. These cultures were used for the observation of colony shape and Gram stain. For detection of endospores, the organisms were cultured in Rober ts cooked meat broth for 5 days (21) and stained with Wirtz stain (27). Estimation of the growth response to sugars was made as follows. Each sugar tested (Table 2) was added to a $3.5-\mathrm{ml}$ portion of PY medium in a small test tube $(10 \mathrm{by} 106 \mathrm{~mm})$ to give a $1 \%(\mathrm{wt} / \mathrm{vol})$ concentration of the sugar. (PY medium consists of $2 \%$ [wt/vol] polypeptone [Daigo, Osaka, Japan], $0.5 \%$ yeast extract, and $0.5 \% \mathrm{NaCl}$.) Each tube was inoculated with a $0.15-\mathrm{ml}$ portion of a liver broth culture. The growth response to each sugar was compared with that in a control tube with no sugar added and was read positive when the optical density of each culture was more than two times as much as that of the control tube. A 0.2-ml portion of $\mathrm{pH}$ indicator consisting of methyl red $(0.1 \mathrm{~g})$, bromthymol blue $(0.3 \mathrm{~g}), 95 \%$ (vol/vol) ethyl alcohol $(300 \mathrm{ml})$, and distilled water $(300 \mathrm{ml})$ was added af ter the estimation of optical density. A change in the $\mathrm{pH}$ indicator from blue to yellow and then to red indicated acid production. To detect anaerobiosis, organisms streaked on $1 \%$ glucose blood (human) agar were incubated aerobically and anaerobically. Hemolysis was determined on the same medium. For detection of capsules, observations were made on an overnight culture $(10 \%$ [vol/vol] serum broth containing $1 \%$ [wt/vol] glucose [9]) stained with India ink. Indole production, nitrate reduction, and liquefaction of 2 and $10 \%$ (wt/vol) gelatin were determined according to the method of Sterne and van Heyningen (23). To test for $\mathrm{H}_{2} \mathrm{~S}$ production, SIM medium (Eiken Chemical Co., Tokyo, Japan) was used. The digestion of casein was determined by Grob's method (7). The production of urease was determined by the method of Brooks and Epps (4). For the digestion of tributyrin, a brain-heart inf usion agar (Eiken Chemical Co., Tokyo, Japan) plate containing $1 \%$ (vol/vol) tributyrin (Wako Co., Osaka, Japan) was used. RNase and deoxyribonuclease (DNase) were detected as follows: RNA was added to a basal medium $(2.5 \%$ [vol/vol] heart infusion [Nissui Co., Tokyo, Japan], $0.045 \% \mathrm{CaCl}_{2}, 0.5 \%$ yeast extract, and $1.5 \%$ [wt/vol] agar) to a final concentration of $0.2 \%$; after $48 \mathrm{~h}$ of incubation at $37 \mathrm{C}, 1.5 \mathrm{~N} \mathrm{HCl}$ was added to detect the transparent zone around the RNase-positive colonies; to test for DNase, the Eiken DNA medium (Eiken Chem., Tokyo, Japan) containing DNA in a concentration of $0.25 \%$ was used; the result was read by the same procedure as used in the RNase test. To test for phosphatase, phenolphthalein-diphosphate (Wako Co., Tokyo, Japan) was added, to a final concentration of $0.15 \%$, to a basal medium ( $\mathrm{pH} 7.2$ ) consisting of $2 \%$ (wt/vol) proteose peptone (Difco), $0.5 \% \quad \mathrm{~K}_{2} \mathrm{HPO}_{4}$, $0.5 \%$ glucose, and $1.5 \%(\mathrm{wt} / \mathrm{vol})$ agar; colonies which developed on the plates were exposed to $\mathrm{NH}_{3}$ gas. To test for collagenase, holes were punched out on plates containing $2 \%(\mathrm{wt} / \mathrm{vol})$ agar and $0.4 \%$ fragmented hide powder $(\mathrm{BDH})$, and $0.5 \mathrm{ml}$ of a 24 -h chopped meat broth culture was pipetted with a drop of chloroform into the holes; a positive test was indicated by the appearance of a clear zone around a hole after $24 \mathrm{~h}$ of incubation at $37 \mathrm{C}$. To test for gas production from glucose, PY medium containing $1 \%$ (wt/vol) glucose and $0.5 \%$ agar was used. Toxigenicity for mice was determined by the use of 6-h-old cultures grown in the medium of Nishida et al. (16). Alcohol and fat ty acid production was detected by gas chromatography according to the method of Moore et al. (13) but using a Shimazu gas chromatography model GC-4A (Shimazu Co., Kyoto, Japan). A stainless steel column (4 $\mathrm{mm}$ inside diameter, $2 \mathrm{~m}$ long) was packed with Resoflex Lac-1-R-296 (Nishio Co., Tokyo, Japan). The chromatograph was operated at $120 \mathrm{C}$ and with a $\mathrm{N}_{2}$ flow of $60 \mathrm{ml} / \mathrm{min}$. The product with the greatest peak on the chromatogram was marked as a main product. 
(This does not mean that the greatest peak represented the major product in the culture, because not all acids are extracted to the same degree by the ether, and the detector is not equally sensitive to all kinds of acids.) To test for deamination, $1 \mathrm{ml}$ of bacterial suspension (1 $\mathrm{mg}$ of $\mathrm{N} / \mathrm{ml}$ ), $0.4 \mathrm{ml}$ of $0.1 \mathrm{M}$ substrate, and $1.0 \mathrm{ml}$ of $0.1 \mathrm{M}$ phosphate buffer ( $\mathrm{pH} 7.2$ ) were mixed and shaken for $4 \mathrm{~h}$ under anaerobic conditions at $37 \mathrm{C}$, and the evolved $\mathrm{NH}_{3}$ was detected by Nessler reagent. The sensitivity of each strain to antibiotics was tested

TABLE 2. Characters determined

\begin{tabular}{|c|c|}
\hline Test & Features scored \\
\hline \multicolumn{2}{|l|}{ Colonies on $10 \%$ glucose blood agar } \\
\hline Growth & Swarming or localized \\
\hline Edge & Entire, uneven, or irregular \\
\hline Surface & Smooth or rough \\
\hline Color & Not colored, white, or green \\
\hline Mucosity & Mucous or not \\
\hline \multicolumn{2}{|l|}{ Morphology of cell } \\
\hline Gram stain & Negative or positive \\
\hline Shape of cell & Straight rod or curved \\
\hline Arrangement & $\begin{array}{l}\text { Occurring singly or clustered, } \\
\text { filamentous or not }\end{array}$ \\
\hline Width & Slender $(<0.5 \mu \mathrm{m})$ or stout $(>0.5 \mu \mathrm{m})$ \\
\hline Spore & $\begin{array}{l}\text { Terminal or not terminal, oval or } \\
\text { spherical, swelling the rods or not }\end{array}$ \\
\hline Capsule & Capsulated or not \\
\hline Anaerobiosis & Anaerobic or microaerophilic \\
\hline Hemolysis & $\begin{array}{l}\text { Negative, incomplete, or complete } \\
\text { haemolysis }\end{array}$ \\
\hline \multicolumn{2}{|l|}{ Growth in PYG broth } \\
\hline At $18 \mathrm{C}$ & Negative or positive \\
\hline At $50 \mathrm{C}$ & Negative or positive \\
\hline Growth stimulation by sugars & Negative or positive \\
\hline $\begin{array}{l}\text { Glucose, maltose, lactose, sucrose, galactose, fructose, xylose, } \\
\text { mannitol, arabinose, salicin, mannose, raffinose, inulin, } \\
\text { sorbitol, adonitol, dulcitol, glycerin }\end{array}$ & \\
\hline \multicolumn{2}{|l|}{ Biological tests } \\
\hline Indole production, nitrate reduction & Negative or positive \\
\hline Gelatin liquefaction & $\begin{array}{l}\text { Negative, weakly positive, or } \\
\text { strongly positive }\end{array}$ \\
\hline Casein digestion & Negative, incomplete, or complete \\
\hline Hydrogen sulfide production & Negative or positive \\
\hline $\begin{array}{l}\text { Enzymatic activity } \\
\text { Lecithinase, urease, RNase, DNase, phosphatase, } \\
\text { collagenase, lipase }\end{array}$ & Negative or positive \\
\hline $\begin{array}{l}\text { Sensitivity to antibiotics } \\
\text { Chloramphenicol, tetracycline, penicillin, erythromycin, } \\
\text { streptomycin, colistin, kanamycin, fradiomycin }\end{array}$ & Sensitive or resistant \\
\hline Toxigenicity to mouse & Toxic or nontoxic \\
\hline Alcohol and fatty acid production in PYG medium & Negative or positive \\
\hline \multicolumn{2}{|l|}{$\begin{array}{l}\text { Butanol, isobutanol, isoamyl alcohol, acetic acid, propionic } \\
\text { acid, isobutyric acid, } n \text {-butyric acid, isovaleric acid, } \\
n \text {-valeric acid, isocaproic acid, } n \text {-caproic acid }\end{array}$} \\
\hline A main product & $\begin{array}{l}\text { Isoamyl alcohol, acetic acid, } n \text {-butyric } \\
\text { acid, iso-valeric acid, } n \text {-valeric acid, } \\
\text { or isocaproic acid }\end{array}$ \\
\hline $\begin{array}{l}\text { Utilization of nitrogen compounds as sole nitrogen and } \\
\text { carbon source }\end{array}$ & Negative or positive \\
\hline L-Glutamic acid & \\
\hline L-Histidine & \\
\hline $\begin{array}{l}\text { Deamination of } \\
\text { L-Aspartic acid, L-glutamic acid, L-Histidine, } \\
\text { L-methionine, DL-serine }\end{array}$ & Negative or positive \\
\hline Gas from glucose & Negative or positive \\
\hline
\end{tabular}


TABLE 3. Lecithinase activities of Clostridium perfringens-like strains

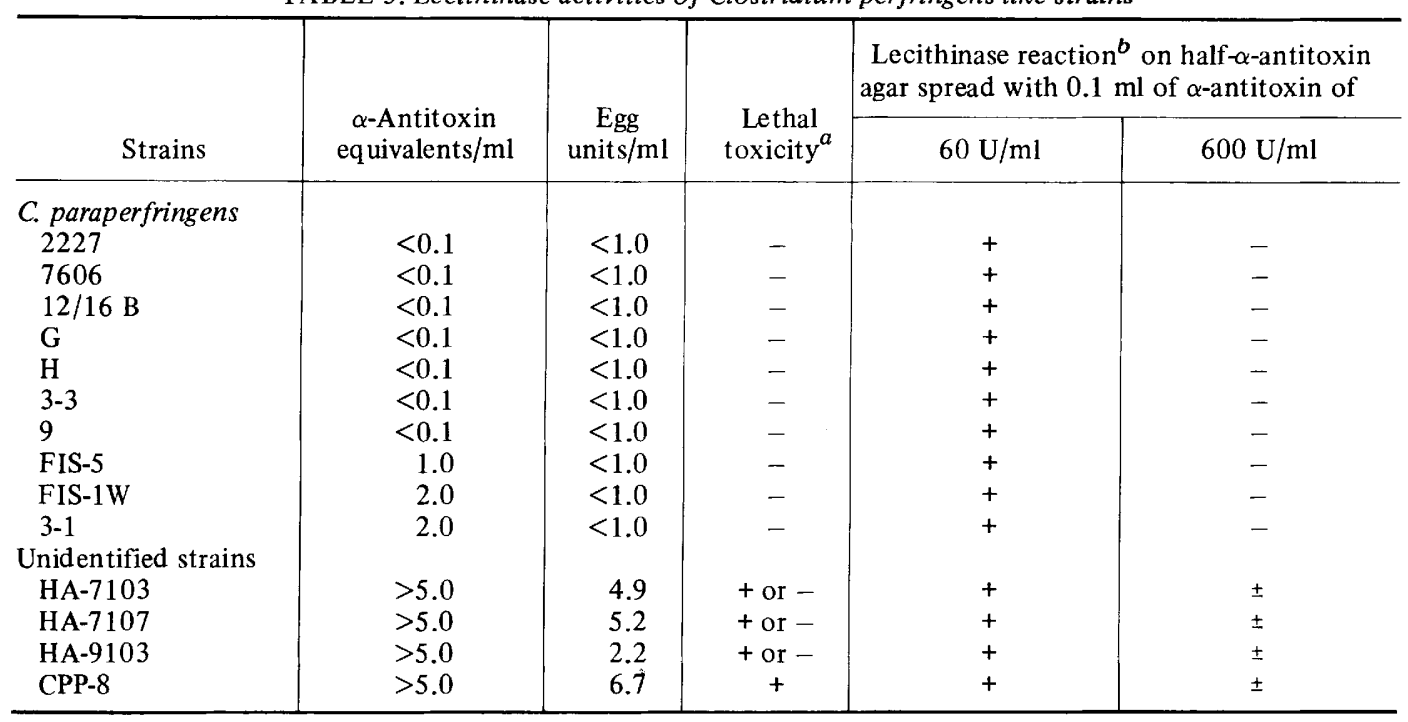

${ }^{a}$ Symbols: + , toxic; - , nontoxic; + or - , inconsistently toxic.

$b$ Symbols: + , lecithinase reaction not suppressed; \pm , lecithinase reaction slightly suppressed; - , lecithinase reaction suppressed; + or -, inconsistently toxic.

by the disk method. In scoring sensitivity to antibiotics, the absence of a zone of inhibition was interpreted as resistance, and an inhibition zone of any size was interpreted as sensitivity to an antibiotic. The utilization of L-glutamic acid and L-histidine as sole nitrogen and carbon sources was determined as follows: to a medium consisting of $0.03 \%$ yeast extract, $0.02 \% \quad \mathrm{KH}_{2} \mathrm{PO}_{4}$, and $0.01 \% \quad \mathrm{MgSO}_{4}$ in a volume of $3.5 \mathrm{ml}$ in a small test tube $(10 \mathrm{by} 106 \mathrm{~mm})$, each amino acid was added to give a final concentration of $0.75 \%$; the medium was inoculated with 0.15 $\mathrm{ml}$ of a liver broth culture; after anaerobic incubation for $48 \mathrm{~h}$ at $37 \mathrm{C}$, the turbidity was estimated by optical density readings. To test for growth at 18 and $50 \mathrm{C}$, a PY medium containing $1 \%$ glucose was used.

\section{RESULTS}

Lecithinase reaction. The zones of the lecithinase reactions around the colonies of $C$. paraperfringens on Nagler agar were definitely thinner than those produced by $C$. perfringens. The lecithinase reaction on half-antitoxin Nagler agar spread with $600 \mathrm{U}$ of alpha-antitoxin was completely suppressed in most cases and was slightly suppressed by $60 \mathrm{U}$ of the antitoxin, although the stronger lecithinase reactions of the $C$. perfringens strains were completely or almost completely suppressed by the $60 \mathrm{U}$ of alpha-antitoxin. Further examination of the lecithinase produced by $C$. paraperfringens strains in chopped meat-broth culture filtrates confirmed the low avidity between the lecithinase of these strains and $C$. perfringens alpha-antitoxin (Table 3). The lecithinase activity, when examined according to the method of van Heyningen, was very slight, less than 1 $\mathrm{EU} / \mathrm{ml}$. However, when the lecithinases of some of the strains were re-examined for combining ability with the alpha-antitoxin, they exhibited $\mathrm{AE}$ titers extraordinarily higher than the titer calculated from the ratio of $\mathrm{AE} / \mathrm{EU}$ of $C$. perfringens alpha-toxin. The lecithinase activities of the remaining strains were so weak that they could not be measured by this method. The new $C$. perfringens-like isolates, HA-7103 (ATCC 27555), HA-7107 (ATCC 27637), HA9103 (ATCC 27635), and CPP-8 (ATCC 27636), were compared with the $C$. paraperfringens and Inflabilis barati strains. The colonial and morphological characteristics of these strains were in agreement with those of $C$. perfringens. The zones of the lecithinase reaction around the colonies of the new isolates grown on Nagler agar were as wide as those of C. perfringens, but the lecithinase reaction on half-antitoxin Nagler agar spread with $600 \mathrm{U}$ of alpha-antitoxin was only slightly suppressed by the antitoxin (Fig. 1). The lecithinase produced by the new isolates in chopped meat-broth cultures exhibited activities as weak as 10 $\mathrm{EU} / \mathrm{ml}$, but the lecithinase reaction could not be neutralized by an excessive amount of the alpha-antitoxin. One strain, CPP-8, was consistently toxigenic to mice, and the remaining strains, HA-7103, HA-7107, and HA-9103, were inconsistently toxigenic.

Computer analysis. Computer studies were 
carried out on $C$. paraperfringens, I. barati, and the new $C$. perfringens-like isolates to determine their taxonomic position with relation to other saccharolytic clostridia and particularly to elucidate correlations, if any, between these strains and $C$. perfringens. The result of these studies, presented as a dendrogram (Fig. 2), show that 53 strains of saccharolytic clostridia are associated at $81 \%$ similarity (81-phenon). In this 81-phenon, seven phenons were separated at $90 \%$ similarity. The remaining strains outside the saccharolytic 81-phenon consist of reference strains of various species of Clostridium.

Phenon I. The mean similarity values (MSV) of each strain to each of the other strains in phenon I ranged between 86 and 93\%. This phenon is linked to phenon II through $C$. perfringens $1278 \mathrm{~A}$ at the $89 \%$ level. However, none of the MSVs of each strain in phenon I to all of the strains in phenon II was more than $81 \%$. This indicates that although both phenons are taxonomically close to each other, they should be sorted into different species. This phenon includes all of the strains of $C$. paraperfringens used in this study.

Phenon II. The MSVs of each strain to each of the other strains in this phenon ranged from 85 to $92 \%$. When the MSVs were compared, that of $C$. perfringens $1278 \mathrm{~A}$ was the lowest. This strain was sent from the Pasteur Institute, Paris, as Inflabilis sanguicole. It was sorted into this phenon because it was linked to $C$. perfringens S16102 at an SV of $91 \%$. When grown on Nagler agar, C. perfringens 1278 A

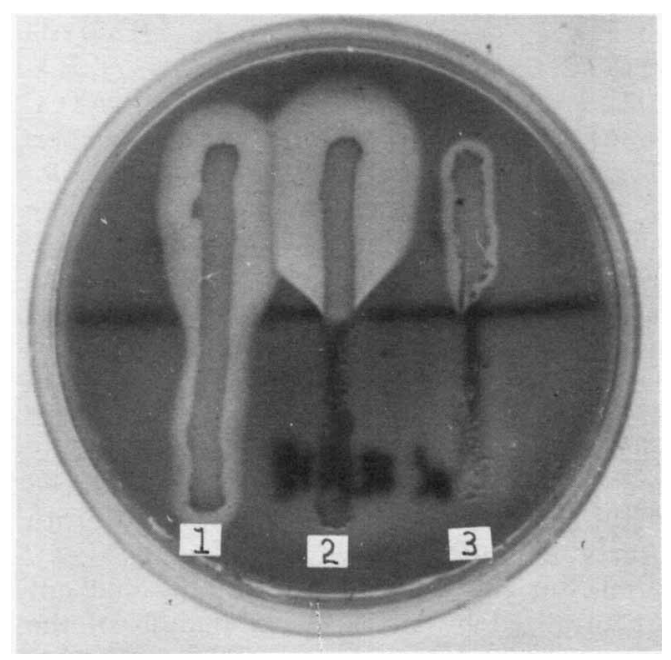

FIG. 1. Lecithinase reaction of Clostridium perfringens and $C$. perfringens-like strains on halfalpha-antitoxin Nagler agar. 1, Strain HA-7103; 2, C. perfringens $P B 6 K ; 3, C$. paraperfringens $H$. showed a distinct lecithinase reaction which was typically inhibited by the alpha-antitoxin of $C$. perfringens. This phenon includes all of the strains of $C$. perfringens studied here.

Phenon III. The three new C. perfringens-like strains included in the computer analysis belonged to this phenon, and each was linked with the other strains of this same phenon at MSVs ranging from 92 to $96 \%$. Each strain in this phenon was linked to the strains in phenon I at MSVs ranging from 80 to $81 \%$ and to those in phenon II at MSVs ranging from 71 to $74 \%$. Another strain, CPP-8, which is cited in Table 3 but was not subjected to computer analysis, was placed in this group when examined for its morphological and biological properties. Culture filtrates of strains belonging to this phenon killed mice when injected intravenously.

Phenon IV. The three strains in this phenon belong to $C$. tertium.

Phenon V. C. multifermentans, C. butyricum, and $C$. acetobutyricum belong to this phenon.

Phenon VI. All strains sorted into this phenon belong to $C$. septicum. They were associated at high SVs. The MSVs of each strain to each of the other strains in this phenon ranged from 94 to $97 \%$.

Phenon VII. This phenon consists only of $C$. chauvoei strains. The MSVs of each strain to each of the other strains of this phenon ranged from 94 to $97 \%$. Phenons VI and VII were associated at fairly high similarities, indicating that $C$. septicum and $C$. chauvoei are taxonomically close to each other.

Phenon VIII. This phenon, which lies outside of the above-mentioned 81-phenon, consists of $C$. difficile strains. Each of these strains is associated at $95 \%$ similarity.

Remaining strains. The remaining strains constitute a heterogenous group consisting of reference strains associated at SVs of less than $86 \%$. They belong to the following species: $C$. sordellii, $C$. bifermentans, $C$. sporogenes, $C$. fallax, C. tetani, and C. tetanomorphum.

The most useful criterion for differentiating C. perfringens (phenon II) and the two groups of $C$. perfringens-like strains (phenons I and III) from the other phenons in the saccharolytic 81-phenon is lecithinase production. Table 4 implies that phenons I and III are fairly similar to each other although both are distinctly different from $C$. perfringens. The most useful criteria for differentiating phenon I from phenon III strains are cell width, the inhibition of lecithinase by 600 Units of $C$. perfringens alpha-antitoxin, the liquefaction of $2 \%$ gelatin, the production of butanol, and the colonial morphology.

DNA-DNA homology. Further attempts to 


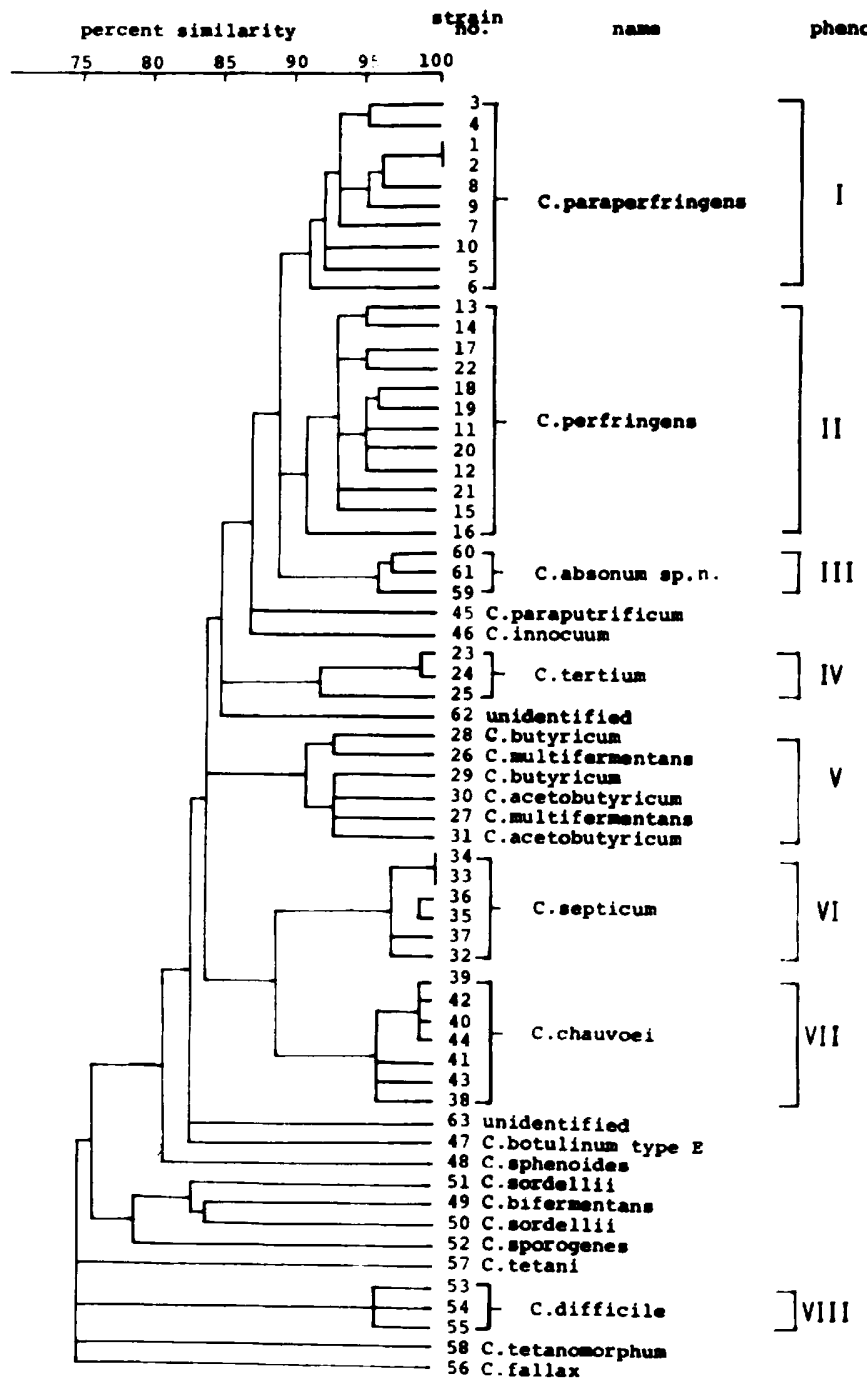

FIG. 2. Dendrogram of strains of saccharolytic clostridia and of selected reference strains.

TABLE 4. Differences between Clostridium perfringens (phenon II) and C. perfringens-like strains (phenons I and III)

\begin{tabular}{|c|c|c|c|}
\hline Features & $\begin{array}{c}\text { Phenon I } \\
\text { C. paraperfringens }\end{array}$ & $\begin{array}{l}\text { Phenon II } \\
\text { C. perfringens }\end{array}$ & $\begin{array}{c}\text { Phenon III } \\
\text { C. absonum sp. n. }\end{array}$ \\
\hline $\begin{array}{l}\text { Width of cells } \\
\text { Colonial morphology } \\
\text { Hemoly sis } \\
\text { Acid from raffinose } \\
\text { Salicin fermentation } \\
\text { Capsule formation } \\
\text { Gelatin liquefaction } \\
\quad 2 \% \\
\quad 10 \% \\
\text { Butanol production } \\
\text { Toxigenicity to mouse } \\
\text { Lecithinase inhibition on } \\
\text { half-antitoxin Nagler agar }\end{array}$ & $\begin{array}{l}0.5-0.6 \mu \mathrm{m} \\
\text { Serrate margin, rough, } \\
\quad \text { not green } \\
-( \pm \text { or }+) \\
- \\
\text { Immediate } \\
\text { Narrow } \\
- \\
- \\
- \\
- \\
\text { Complete }\end{array}$ & $\begin{array}{l}1.0-1.5 \mu \mathrm{m} \\
\text { Entire round, smooth, } \\
\quad \text { green } \\
+ \\
+ \\
\text { Delayed or none } \\
\text { Wide } \\
+ \\
+ \\
+ \\
+ \\
\text { Complete }\end{array}$ & $\begin{array}{l}0.9-1.0 \mu \mathrm{m} \\
\text { Entire, round, smooth, } \\
\quad \text { green (weak) } \\
+ \\
\text { Immediate } \\
\text { Narrow } \\
+ \\
- \\
+ \\
+ \text { or - } \\
\text { Slight }\end{array}$ \\
\hline
\end{tabular}


TABLE 5. DNA-DNA hybridization

\begin{tabular}{|c|c|c|c|}
\hline \multirow[b]{2}{*}{ Labeled DNA } & \multicolumn{3}{|c|}{ Homology (\%) } \\
\hline & $\begin{array}{l}\text { Phenon I } \\
\text { Clostridium para- } \\
\text { perfringens } \\
(2227)\end{array}$ & $\begin{array}{l}\text { Phenon II } \\
\text { C. perfringens } \\
\text { (PB6K) }\end{array}$ & $\begin{array}{l}\text { Phenon III } \\
\text { C. absonum sp.n. } \\
\text { (HA-7103) }\end{array}$ \\
\hline \multicolumn{4}{|l|}{ Phenon I } \\
\hline Clostridium paraperfringens 2227 & 100 & 17 & 28 \\
\hline C. paraperfringens $3-3$ & 67 & 12 & 29 \\
\hline C. paraperfringens 9 & 75 & 14 & 42 \\
\hline C. paraperfringens $\mathrm{G}$ & 95 & 14 & 43 \\
\hline \multicolumn{4}{|l|}{ Phenon II } \\
\hline$C$ : perfringens type A PB6K & 13 & 100 & 14 \\
\hline C. perfringens type A S002-3 & 16 & 76 & 17 \\
\hline C. perfringens type B 4964 & & 65 & \\
\hline C. perfringens type C 3182 & & 74 & \\
\hline C. perfringens type E 411 & 13 & 92 & 15 \\
\hline C. perfringens type $\mathrm{F} 410$ & 12 & 66 & 11 \\
\hline C. perfringens type A 1278 A & 12 & 71 & 17 \\
\hline \multicolumn{4}{|l|}{ Phenon III } \\
\hline C. absonum sp.n. HA-7103 & 37 & 10 & 100 \\
\hline C. absonum sp.n. HA-7107 & 38 & 7 & 100 \\
\hline C. absonum sp.n. HA-9103 & 34 & 12 & 95 \\
\hline \multicolumn{4}{|l|}{ Reference strains } \\
\hline C. tertium $4 \mathrm{C}-2$ & 14 & 10 & 14 \\
\hline C. butyricum 3858 & 11 & 9 & 13 \\
\hline C. septicum 7281 & 17 & 12 & 17 \\
\hline
\end{tabular}

elucidate the taxonomic relatedness of the strains of phenons I, II, and III were made by studying their DNA-DNA homologies. The hybridization results (Table 5) and the abovementioned computer analysis results agree in showing that the strains of phenons I, II, and III constitute three distinct groups and that phenon III is more closely related to phenon I than to phenon II (Table 5).

\section{DISCUSSION}

Due to differences in the morphological, biological, and lecithinase properties, as well as to the DNA-DNA homologies of phenons I, II, and III, we regard these three phenons as constituting separate but closely related species, and the $C$. perfringens-like strains of phenon III we consider to belong to a new species, for which we propose the name Clostridium absonum. A description of this species follows.

Clostridium absonum sp. nov. (L. adj. $a b$ sonus deviating [intended to mean "deviating from $C$. perfringens"].)

Gram positive, straight rods, 0.9 to 1.3 by 4.0 to $12.0 \mu \mathrm{m}$. Not motile. Spores oval, eccentric to subterminal, not swelling the cells.
Surface colonies are circular, 1 to $3 \mathrm{~mm}$ in diameter, raised, slightly green.

Profuse and rapid growth in broth with fermentable carbohydrates.

Ferments fructose, galactose, glucose, lactose, maltose, mannose, salicin, and sucrose; does not ferment adonitol, arabinose, dulcitol, inulin, mannitol, raffinose, or sorbitol.

Fermentation products include acetic and butyric acids and butanol.

Gelatin is slowly liquefied. Milk is digested; frequently there is a storming of the milk. Urease is not produced. Nitrate is reduced.

Blood agar (human blood) is completely hemolyzed. Lecithinase is produced on egg-yolk agar. Lipase is not produced.

Anaerobic.

Toxin is weakly produced by most strains.

Habitat: widely distributed in soil.

Type strain. The type strain is HA-7103. It has been deposited in the American Type Culture Collection (ATCC), Rockville, Md., as ATCC 27555.

Phenon I includes three named strains which were sent from the Pasteur Institute, Paris. Two of them, 2227 and 7606, were labeled Inflabilis barati. Prévot $(17,20)$ stated that $I$. barati was the same as "le Bacille de Barat." The two 
strains of $I$. barati, however, exhibited cultural properties distinctively different from those given in the original description of "le Bacille de Barat" by Tissier (24). Although Tissier stated that his strains formed round spores, produced the characteristic "limande" form, contained granules stainable by iodine solution, were motile, could grow rapidly and abundantly in the absence of sugars as well as in the presence of them, caused stormy fermentation of milk as $C$. perfringens did, produced no volatile fatty acid except acetic acid, fermented mannitol, and attacked fats, the two strains of the Pasteur Institute differed from "le Bacille de Barat" in all of the above-mentioned characters. The two strains, however, were demonstrated to be in agreement with $C$. paraperfringens in their cultural and biological properties and, therefore, were renamed as $C$. paraperfringens. A detailed description of $\mathrm{Clo}$ stridium paraperfringens follows.

Clostridium paraperfringens Nakamura et al. Straight rods, 0.5 to 0.6 by 1.3 to $6.7 \mu \mathrm{m}$. Gram positive. Not motile. Spores oval, eccentric to subterminal, swelling the cells.

Surface colonies are circular, 0.5 to $1.0 \mathrm{~mm}$ in diameter, slightly raised, and translucent with a dull, smooth surface, but colonies are frequently rhizoid, 2 to $4 \mathrm{~mm}$ in diameter, flat, and slightly grayish with a matt surface.

Growth is moderately good in liquid media with fermentable sugars but is poor in sugarfree media; diffuse turbidity.

Ferments cellobiose, fructose, galactose, glucose, lactose, maltose, mannose, salicin, starch, and sucrose. Variable on ribose, melibiose, and trehalose. Does not ferment adonitol, arabinose, dulcitol, esculin, glycerol, inositol, inulin, mannitol, melezitose, raffinose, rhamnose, sorbitol, or xylose. Fermentation products include acetic and butyric acids without butanol.

Casein and gelatin are not hydrolyzed. Milk becomes acid but is otherwise unchanged.

Hydrogen sulfide is produced; indole is not formed. Urease is not formed; nitrate is reduced by most strains. Blood agar (human blood) is incompletely hemolyzed by some strains. Lecithinase is produced on egg-yolk agar; lipase is not produced. Anaerobic. Toxin is not formed; nonpathogenic for mice. Optimal temperature for growth, 35 to $45 \mathrm{C}$. Isolated from the normal human intestine and from wounds.

Type strain. Because a type strain was not designated for $C$. paraperfringens when this organism was originally named and described (15), strain G, one of the strains on which the original description was based, is here designated as the type strain. It has been deposited in the American Type Culture Collection, Rockville, Md., as ATCC 27639. Two additional strains, 3-3 and 2227, have been deposited in the American Type Culture Collection as ATCC 27640 and ATCC 27638, respectively.

Also included in phenon I was another named strain, Inflabilis lacustris $12 / 16 \mathrm{~B}$. We received two strains of $I$. lacustris, $12 / 16 \mathrm{~B}$ and $12 / 16 \mathrm{C}$, from the Pasteur Institute. However, when subjected to a computer analysis, the two were linked to each other at a low SV $(70 \%)$. In checking the authenticity of these strains, we found that $12 / 16 \mathrm{~B}$ differed from the original description of I. lacustris (19) in many important respects: strain $12 / 16 \mathrm{~B}$ was urease-negative, did not produce a foul odor, did not produce indole, and produced capsules. The incorrectly labeled I. lacustris $12 / 16$ B was re-identified as $C$. paraperfringens. On the other hand, the morphological, cultural, and biological properties of strain $12 / 16 \mathrm{C}$ were in agreement with those of $C$. sordellii. The genus Inflabilis, which is not recognized in the present edition of Bergey's Manual (3), is clearly inappropriate for the three strains mentioned above. Although Prévot (17) stated that strains of the genus Inflabilis were not encapsulated, we could demonstrate the presence of capsules in the three strains received from the Pasteur Institute as well as in our $C$. paraperfringens isolates by the use of $10 \%$ serum broth containing $1 \%$ glucose, although the capsule was definitely thinner than that of $C$. perfringens.

Inflabilis setiensis (18), described in Prévot's Manual (17), is designated Clostridium setiense (Prévot and Raynaud) by McClung and McCoy in Bergey's Manual (3). The two strains of $I$. setiensis (2866 and 3131) examined by us, however, exhibited biological properties distinctly different from those reported by Prévot himself. I. setiensis 2866 was associated with $C$. difficile ATCC 17857 and ATCC 9689 at SVs as high as 95 and $96 \%$, respectively. I. setiensis 3131 did not attack any sugar examined, and we did not include this strain in the computer analysis. We have received a few other strains of the genus Inflabilis from the Pasteur Institute. Most of the strains identified as belonging to this genus seemed to necessitate further investigation before being established as distinct species. Our results demonstrated that $C$. multifermentans, $C$. butyricum, and $C$. acetobutyricum belonged to the same phenon. A recent investigation (5) revealed that strains designated as Clostridium butyricum constituted two distinct groups on the basis of 
cell-wall sugar patterns, nucleotide-sequence similarities of DNA preparations, and nutritional requirements.

Also, DNA-DNA homology tests revealed that phenon I strains belong to a species distinctly different from $C$. perfringens and that $C$. absonum is not related to $C$. perfringens and is related only at a low level of homology to phenon I strains.

\section{ACKNOWLEDGMENTS}

We thank Chi Tu Huang, Hong Kong University, Hong Kong, Louis D. S. Smith, Virginia Polytechnic Institute, Blacksburg, and E. F. Lessel, American Type Culture Collection, Rockville, Md., for their useful discussions. We also express our gratitude to $C$. Mills of the American Type Culture Collection, S. Lapage of the National Collection of Type Cultures, London, England, B. D. Bychenko of the L. A. Tarassevich State Control Institute, Moscow, U.S.S.R., P. Høgh of the State Veterinary Serum Laboratory, Copenhagen, Denmark, R. Murata of the National Institutes of Health, Tokyo, Japan, E. Kodama of the Akita Hygiene Institute, Akita, Japan, T. Hasegawa of the Institute for Fermentation, Osaka, Japan, and the Pasteur Institute, Paris, for supplying strains used in this study. We thank Y. Kato, Osaka City Institute for Hygiene, Osaka, Japan, for his advice on the techniques used in determining the DNA-DNA homologies.

\section{REPRINT REQUESTS}

Address requests for reprints to: Dr. Shinichi Nakamura, Department of Bacteriology, School of Medicine, Kanazawa University, Kanazawa, Japan.

\section{LITERATURE CITED}

1. Batty, I., and P. D. Walker. 1963. Differentiation of Clostridium septicum and Clostridium chauvoei by the use of fluorescent antibodies. J. Pathol. Bacteriol. 35:517-521.

2. Beers, R. J., J. Fischer, B. S. Magraw, and W. R. Lockhart. 1965. A comparison of methods for computer taxonomy. J. Gen. Microbiol. 28:641-652.

3. Breed, R. S., E. G. D. Murray, and N. R. Smith. 1957. Bergey's manual of determinative bacteriology, 7th ed., p. 677-678. Williams \& Wilkins, Baltimore.

4. Brooks, M. E., and H. B. G. Epps. 1959. Taxonomic studies of the genus Clostridium: Clostridium bifermentans and Clostridium sordellii. J. Gen. Microbiol. 21:144-155.

5. Cummins, C. S., and J. L. Johnson. 1971. Taxonomy of the clostridia: Clostridium butyricium and other butyric acid-producing clostridia. J. Gen. Microbiol. 67:33-46.
6. Evans, D. G. 1945. The in-vivo production of alpha-toxin, theta-haemolysin and hyaluronidase by strains of Clostridium welchii type $\mathrm{A}$ and the relationship of in-vitro properties to virulence in guinea pigs. J. Pathol. Bacteriol. 57:75-85.

7. Grob, D. 1964. Proteolytic enzymes. I. The control of their activity. J. Gen. Physiol. 29:219-245.

8. Hanaoka, M., Y. Kato, and T. Amano. 1969. Complementary examination of DNA's among Vibrio species. Biken J. 12:181-185.

9. Keppie, J., and M. Robertson. 1944. The in-vitro toxigenicity and other characters of strains of $\mathrm{Cl}$. welchii type A from wounds sources. J. Bacteriol. Pathol. 56:123-132.

10. McCarthy, B. J., and E. T. Bolton. 1963. An approach to the measurement of genetic relatedness among organisms. Proc. Nat. Acad. Sci. U.S.A. 50:156-164.

11. McCarthy, B. J., and B. H. Hoyer. 1964. Identity of DNA and diversity of messenger RNA molecules in normal mouse tissues. Proc. Nat. Acad. Sci. U.S.A. 52:915-922.

12. Marmur, J. 1961. A principle for the isolation of desoxyribonucleic acid from microorganisms. J. Mol. Biol. 3:208-218.

13. Moore, W. E. C., E. P. Cato, and L. V. Holdeman. 1966. Fermentation patterns of some clostridia species. Int. J. Syst. Bacteriol. 16:383-415.

14. Moussa, R. S. 1959. Complexity of toxins from Clostridium septicum and Clostridium chauvoei. J. Bacteriol. 76:583-545.

15. Nakamura, S., K. Tamai, and S. Nishida. 1970. Criteria for identification of Clostridium perfringens. 6. Clostridium paraperfringens $\mathrm{sp}$. nov. Med. Biol. 80:137-140.

16. Nishida, S., M. Murakami, and T. Yamagishi. 1962. Chopped meat broth as a medium for the production of toxins by clostridia. I. Production of toxins by Clostridium welchii. Jap. J. Microbiol. 6:33-40.

17. Prévot, A. R. 1957. Manual de classification et de détermination des bactéries anaérobies, $p$. 162-163. Masson et Compagnie, Paris.

18. Prévot, A. R., and M. Raynaud. 1944. Sur une nouvelle éspece anaerobié isolée de l'huitre. Inflabilis setiensis sp. n. Ann. Inst. Past. 70:50-51.

19. Prévot, A. R., H. Thouvenot, M. Patricalla, and R. Silloc. 1956. Une nouvelle éspece anaerobié des lacs du Ruwenzor: Inflabilis lacustris sp.n. Ann. Inst. Past. 91:929-932.

20. Prévot, A. R., A. Turpin, and P. Kaiser. 1967. Les bactéries anaérobies, p. 606. Dunod, Paris.

21. Roberts, T. A. 1967. Sporulation of mesophilic clostridia. J. Appl. Bacteriol. 30:430-443.

22. Sneath, P. H. A. 1957. The application of computers to taxonomy. J. Gen. Microbiol. 17:201-221.

23. Sterne, M., and W. E. van Heyningen. 1958. Clostridia, p. 545-575. In R. J. Dubos and J. G. Hirsh (ed.), Bacterial and mycotic infections of man, 4th ed. Lippincott Co., Philadelphia.

24. Tissier, H. 1918. La bacille de Barat. C. R. Soc. Biol. (Paris) 81:426-427. 
25. van Heyningen, W. E. 1941. The biochemistry of the gangrene toxins. I. Estimation of the alphaantitoxin of $\mathrm{Cl}$. welchii type A. Biochem. J. 35:1246-1256.

26. Willis, A. T., and G. Hobbs. 1958. A medium for the identification of clostridia producing opalescence in egg yolk emulsion. J. Pathol. Bacteriol.
75:299-305.

27. Wirtz, K. 1908. Eine einfache Art der Sporenfärbung. Zentralbl. Bakteriol. Parasitenk. Infektionskr. Hyg. Abt. Orig. 46:727-728.

28. Yamagishi, T., S. Ishida, and S. Nishida. 1964. Isolation of toxigenic strains of Clostridium perfringens. J. Bacteriol. 88:646-652. 